\title{
Upaya Memikat Generasi Muda Bekerja pada Sektor Pertanian di Daerah Istimewa Yogyakarta
}

\section{Efforts of Engage Youth Generation to Working on Agricultural Sector in Yogyakarta Province}

\author{
Agus Dwi Nugroho*, Lestari Rahayu Waluyati \& Jamhari \\ Program Studi Agrobisnis, Fakultas Pertanian, Universitas Gadjah Mada, Indonesia.
}

\begin{abstract}
Abstrak
Tujuan dari kajian ini adalah mengidentifikasi kondisi tenaga kerja sektor pertanian; penyebab, dampak dan strategi untuk mengurangi pergeseran angkatan kerja muda dari sektor pertanian ke non pertanian. Penelitian ini dilaksanakan di Kabupaten Bantul, Gunungkidul, Kulon Progo dan Sleman pada tahun 2015. Hasil penelitian menunjukkan jumlah rumah tangga dan perusahaan pertanian di DIY mengalami penurunan. Partisipasi generasi muda di sektor pertanian semakin menurun serta struktur usia tenaga kerja pertanian di DIY didominasi petani berusia 60 tahun ke atas. Faktor pendorong pergeseran generasi muda dari sektor pertanian ke sektor nonpertanian antara lain pendapatan di luar sektor pertanian lebih besar dibandingkan sektor pertanian, image negatif tentang pertanian, peningkatan pendidikan, kepemilikan lahan pertanian yang sempit dan kemudahan aksesbilitas pedesaan. Sedangkan faktor penarik generasi muda ke sektor pertanian antara lain finansial, warisan orang tua dan insentif pemerintah. Adapun dampak pergeseran tersebut antara lain penurunan efektivitas dan efisiensi sektor pertanian serta kelangkaan tenaga kerja pertanian dan kenaikan upah. Untuk mengatasinya maka diperlukan kebijakan antara lain meningkatkan peran pemuda dalam kelembagaan pertanian; pengenalan pertanian melalui pendidikan usia dini; peningkatan kualitas pelaku pertanian; mengembangkan pertanian terpadu; penguatan cooperative farming; asuransi pertanian dan jaminan pemasaran.
\end{abstract}

Kata Kunci: Tenaga Kerja, Generasi Muda, Pertanian, Faktor Pendorong, Faktor Penarik

\begin{abstract}
The purposes of this study was to identify the condition of agricultural labor; know the causes, impacts and strategies to reduce the shift of the youth labor from agricultural to non-agricultural sector. This research was conducted in Bantul, Gunungkidul, Kulon Progo and Sleman regency in 2015. The results showed that the number of households and agricultural enterprises in DIY decrease. The participation of youth in agricultural sector had been decline and the age of agricultural labor DIY was dominated by the farmers over 60 years. Factors which push the shift of the youth from agricultural to non-agricultural was the bigger income on non-agricultural sector, negative image of agriculture, increase of education, narrow land ownership and ease of rural accessibility. While the factors of pull the youth was financial, parental inheritance and government incentives. The impacts of this condition was decrease of the effectiveness and efficiency of agriculture; the scarcity of agricultural labor and increase of the wage. To overcome this, it is necessary to increase the role of youth in the farmers' institutions; introduction of agriculture through early childhood education; improve the quality of agricultural actors; develope integrated agriculture; strengthen cooperative farming; agricultural insurance and marketing guarantees.
\end{abstract}

Keywords: Labor, Youth, Agriculture, Push Factor, Pull Factor

How to Cite: Nugroho, A.D. Waluyati, L.R. \& Jamhari (2018). Upaya Memikat Generasi Muda Bekerja pada Sektor Pertanian di Daerah Istimewa Yogyakarta. JPPUMA: Jurnal Ilmu Pemerintahan dan Sosial Politik UMA, 6 (1): 76-95.

*Corresponding author: ISSN 2549-1660 (Print)

E-mail: agus.dwi.n@mail.ugm.ac.id ISSN 2550-1305 (Online) 


\section{PENDAHULUAN}

Perubahan struktur ekonomi nasional dalam 4 (empat) dekade terakhir terjadi sangat cepat dimana sektor industri menjadi tumpuan pembangunan ekonomi sementara sektor lain, terutama pertanian, menjadi sektor pendukung. Perubahan struktur ekonomi tidak diimbangi dengan pemerataan distribusi pendapatan sehingga terjadi ketimpangan pendapatan antarsektor. Perputaran modal di sektor industri yang cukup besar akan memberikan pendapatan yang besar pula bagi pelaku sektor ini namun hanya terdistribusi bagi pelaku sektor industri yang jumlahnya relaitf kecil dibandingkan pelaku usaha sektor pertanian. Perubahan struktur ekonomi nasional berdampak pula pada perubahan luasan lahan pertanian dan komposisi tenaga kerja.

Alih fungsi lahan pertanian ke non pertanian terus terjadi di Indonesia. Peningkatan pertumbuhan penduduk dan perkembangan sektor ekonomi yang cepat menyebabkan luasan lahan pertanian di Indonesia terus berkurang rata-rata sebesar 110.000 ha per tahun. Angka ini lebih tinggi daripada program pencetakan sawah oleh pemerintah yang berkisar 47.000 ha per tahun. Alih fungsi lahan pertanian akan berdampak pada menurunnya produksi pangan sehingga mengancam kemandirian pangan serta pemubadziran investasi untuk infrastruktur pertanian, terutama saluran irigasi.

Perubahan ekonomi juga berdampak pada perubahan komposisi kebutuhan tenaga kerja antarsektor yang menjadi sangat tidak merata karena hanya beberapa sektor usaha yang diminati sebagian besar masyarakat Indonesia. Sektor pertanian, perdagangan, hotel serta restoran masih memiliki kebutuhan tenaga kerja terbanyak dibandingkan dengan sektor usaha lainnya. Tingginya kebutuhan tenaga kerja sektor pertanian karena mayoritas penduduk Indonesia tinggal di kawasan perdesaan. Namun dalam kondisi riil, sektor non pertanian merupakan sektor yang tidak banyak diminati masyarakat sehingga mengakibatkan adanya mobilitas tenaga kerja sektor pertanian ke non pertanian. Kondisi ini terjadi merata di seluruh wilayah Indonesia, termasuk di Daerah Istimewa Yogyakarta (DIY).

Perkembangan serapan tenaga kerja di Daerah Istimewa Yogyakarta dari tahun 19962015 menunjukkan pola yang meningkat kecuali sektor pertanian. Peningkatan penyerapan tenaga kerja tertinggi yaitu berada pada sektor perdagangan, hotel, dan restoran sebanyak 11.346 tenaga kerja setiap tahunnya. Sektor jasa mengalami peningkatan sebanyak 7.045 tenaga kerja setiap tahunnya. Keadaan yang perlu menjadi perhatian adalah sektor pertanian yang mempunyai pola penurunan jumlah tenaga kerja setiap tahunnya mulai dari tahun 2007 hingga tahun 2015. Melihat dari tren, sektor pertanian mengalami penurunan tenaga kerja sebanyak 4.247 tenaga kerja setiap tahunnya. Hal ini menginformasikan bahwa terdapat perpindahan atau transformasi tenaga kerja dari sektor pertanian ke sektor non pertanian. 
Agus Dwi Nugroho, Lestari Rahayu Waluyati \& Jamhari. Upaya Memikat Generasi Muda Bekerja

Untuk meningkatkan minat generasi muda pada sektor pertanian maka diperlukan suatu desain kebijakan secara intensif dan terstruktur dalam rangka pemberdayaan tenaga kerja sehingga akan berpengaruh pada kepada peningkatan produksi/produktivitas pertanian.pendapatan petani dan pertumbuhan ekonomi. Tujuan dari kajian ini adalah mengidentifikasi kondisi tenaga kerja sektor pertanian DIY saat ini dan faktor penyebab terjadinya pergeseran angkatan kerja muda dari sektor pertanian ke non pertanian; mempelajari dampak pergeseran angkatan kerja muda dari sektor pertanian ke non pertanian; dan menyusun strategi untuk mengurangi pergeseran angkatan kerja muda dari sektor pertanian ke non pertanian di DIY

\section{METODE PENELITIAN}

Kegiatan penelitian ini dilaksanakan di 4 (empat) kabupaten di DIY yakni Bantul, Gunungkidul, Kulon Progo dan Sleman pada tahun 2015. Data terdiri atas data primer yang diperoleh langsung di lapangan melalui observasi, wawancara dan FGD kepada petani dan dinas pertanian provinsi maupun kabupaten. Selain itu penelitian ini menggunakan data sekunder yang diperoleh dari sumber-sumber instansi terkait untuk mengidentifikasi kondisi tenaga kerja sektor pertanian saat ini dan penyebab serta dampak terjadinya pergeseran angkatan kerja muda dari sektor pertanian ke non pertanian.

Metode analisis yang digunakan dalam penelitian ini adalah: Untuk mengetahui kondisi tenga kerja pertanian ini maka dilakukan analisis kualitatif berdasarkan wawancara dengan instansi terkait dan pengelola usaha pertanian. Analisis kuantitatif juga akan dilakukan dengan berdasarkan data yang dikumpulkan dari instansi terkait; Untuk mengetahui penyebab serta dampak terjadinya pergeseran angkatan kerja muda dari pertanian ke non pertanian dengan wawancara responden serta studi literature; Untuk menyusun strategi mengurangi pergeseran angkatan kerja muda dari sektor pertanian ke non pertanian di DIY maka digunakan analisis kebijakan.

\section{HASIL DAN PEMBAHASAN}

\section{Gambaran Umum Tenaga Kerja Pertanian di DIY}

Sektor pertanian di DIY mengalami penurunan tenaga kerja yang cukup besar dalam 1 dekade terakhir. Jumlah rumah tangga pertanian pada tahun 2013 sebesar 495.781 rumah tangga sedangkan pada tahun 2003 sebesar 574.920 rumah tangga atau turun 79.139 rumah tangga $(13,77 \%)$. Penurunan rumah tangga pertanian terjadi hampir di seluruh kabupaten di DIY dengan penurunan absolut terbesar di Sleman dan penurunan secara persentase terbesar ada di Kota Yogyakarta.

Penurunan rumah tangga pertanian di DIY terjadi pada subsektor tanaman pangan, hortikultura, perkebunan dan peternakan. Penurunan terbesar pada subsektor hortikultura dengan persentase 19,13\% dalam 1 dekade terakhir. Sedangkan usaha perikanan mengalami kenaikan jumlah rumah tangga 
yang mengusahakan dimana kenaikan terbesar untuk usaha perikanan darat. Kenaikan jumlah rumah tangga juga terjadi pada usaha subsektor kehutanan.

Usaha pertanian berbadan hukum di DIY dari tahun 2003 ke 2013 mengalami penurunan sebesar 54,55\%. Hampir seluruh subsektor mengalami penurunan usaha pertanian berbadan hukum, kecuali subsektor tanaman pangan. Untuk penurunan perusahaan terbesar adalah perusahaan peternakan sedangkan perusahaan pertanian berbadan hUkum yang mengalami kenaikan terbesar adalah tanaman padi.

\begin{tabular}{|c|c|c|c|c|c|c|c|c|c|}
\hline \multirow{3}{*}{$\begin{array}{l}\text { Kabupaten/ } \\
\text { Kota }\end{array}$} & \multicolumn{4}{|c|}{$\begin{array}{l}\text { Rumah Tangga Usaha Pertanian } \\
\text { (RumahTangga) }\end{array}$} & \multicolumn{4}{|c|}{$\begin{array}{c}\text { Perusahaan Pertanian Berbadan } \\
\text { Hukum (Perusahaan) }\end{array}$} & \multirow{3}{*}{$\begin{array}{c}\text { Usaha } \\
\text { Pertanian } \\
\text { Lainnya } \\
2013 \text { (Unit }\end{array}$} \\
\hline & \multirow{2}{*}{2003} & \multirow{2}{*}{2013} & \multicolumn{2}{|c|}{ Pertumbuhan } & \multirow{2}{*}{2003} & \multirow{2}{*}{2013} & \multicolumn{2}{|c|}{ Pertumbuhan } & \\
\hline & & & Absolut & $\%$ & & & Absolut & $\%$ & \\
\hline Kulon Progo & 94,860 & 88,678 & $-6,182$ & -6.52 & 4 & 3 & -1 & -25.00 & 8 \\
\hline Bantul & 154,288 & 127,894 & $-26,394$ & -17.11 & 7 & 2 & -5 & -71.43 & 52 \\
\hline Gunungkidul & 174,190 & 166,330 & $-7,860$ & -4.51 & 7 & 10 & 3 & 42.86 & 6 \\
\hline Sleman & 144,698 & 110,402 & $-34,296$ & -23.70 & 23 & 4 & -19 & -82.61 & 22 \\
\hline Yogyakarta & 6,884 & 2,477 & $-4,407$ & -64.02 & 3 & 1 & -2 & -66.67 & 2 \\
\hline DIY & 574,920 & 495,781 & $-79,139$ & -13.77 & 44 & 20 & -24 & -54.55 & 90 \\
\hline
\end{tabular}

Sumber: Sensus Pertanian 2013

Apabila dilihat dari jumlah angkatan kerja, selama 1996-2015 terakhir terjadi penurunan angkatan kerja sektor pertanian sebesar $0,10 \%$ per tahun. Apabila rentang waktu 1996 sampai 2015 dibagi menjadi dua fase yaitu antara 1996 sampai 2005 dan antara tahun 2006 sampai tahun 2015 maka didapatkan fenomena yang cukup menarik yaitu pada kurun waktu tahun 1996 sampai tahun 2005 pertumbuhan tenaga kerja lainnya.

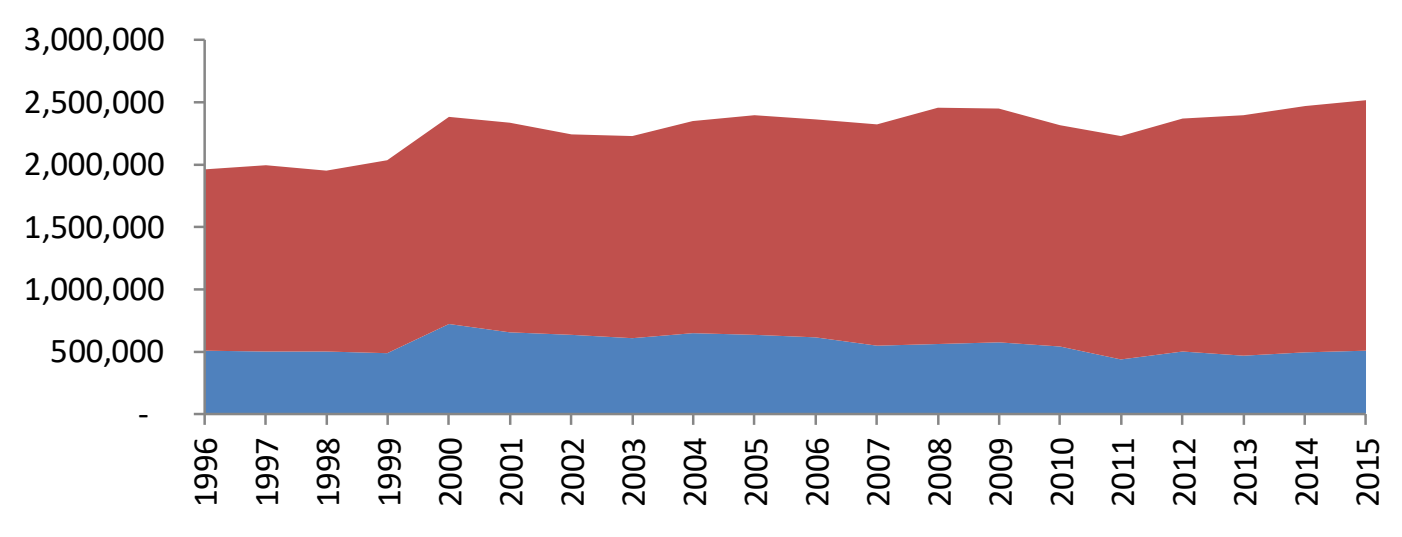

- Tenaga Kerja di Sektor Pertanian DIY

- Total Tenaga Kerja di DIY

Sumber: BPS, (diolah dari berbagai tahun) 
Jumlah tenaga kerja pertanian lanjut. Generasi muda lebih tertarik dengan mengalami penurunan hampir di semua kegiatan pertanian tanaman perkebunan dan kelompok usia. Jumlah generasi muda yang beraktivitas di pertanian yakni tenaga kerja pertanian berusia kurang dari 35 tahun masih sedikit bahkan diproyeksikan akan terus menurun sedangkan petani berusia lanjut terus akan meingkat. Hasil penelitian Prawesti, dkk (2010) menunjukkan bahwa profesi saat ini dianggap tidak prestisius bagi generasi muda karena keadaan petani yang cenderung miskin. Hal ini menyebabkan hanya 26,67\% anak petani yang memiliki motivasi tinggi untuk menjadi petani. Keadaan ini juga terjadi di Irlandia dimana anak petani yang telah bermigrasi ke kota untuk menempuh jenjang pendidikan Perguruan Tinggi cenderung tidak menyukai untuk bekerja di sektor pertanian (Cassidy and Mcgrath, 2015).

Tabel 2 Jumlah Rumah Tangga Usaha Pertanian Menurut Kelompok Umur Kepala Rumah Tangga Tahun 2013

\begin{tabular}{lllll}
\hline $\begin{array}{l}\text { Kelompok } \\
\text { Umur } \\
\begin{array}{l}\text { Petani } \\
\text { Utama }\end{array}\end{array}$ & Jumlah & $\%$ & Jumlah & $\%$ \\
\cline { 2 - 5 }$<15$ & 103 & 0,02 & 1 & 0 \\
$15-24$ & 4.055 & 0.71 & 677 & 0.14 \\
$25-34$ & 38.049 & 6.62 & 24,339 & 4.91 \\
$35-44$ & 117.129 & 20.37 & 92,541 & 18.67 \\
$45-54$ & 131.865 & 22.94 & 134,647 & 27.16 \\
$55-64$ & 153.187 & 26.64 & 117,918 & 23.78 \\
$65+$ & 130.531 & 22.7 & 125,658 & 25.35 \\
\hline DIY & 574,920 & 100,00 & 495,781 & 100 \\
\hline
\end{tabular}

Sumber: Sensus Pertanian 2003 \& 2013

Secara detail, keadaan tiap kabupaten adalah sebagai berikut:

\section{a. Kabupaten Gunungkidul}

Pertanian tanaman pangan di Gunungkidul didominasi oleh petani berusia hortikultura. Permasalahan rendahnya minat generasi muda beraktivitas di pertanian antara lain disebabkan kepemilikan lahan pertanian yang sempit, waktu bercocok tanam pendek (curah hujan rendah), komoditas tidak berubah atau cenderung dengan tanaman padi serta harga hasil panen berfluktuasi. Untuk mengatasi hal tersebut, Dinas Pertanian Gunungkidul telah membuat perencanaan pengembangan pertanian yakni di Sriten (Gunungkidul bagian utara), Gunung Batur (Gunungkidul bagian selatan), Tambakromo (perbatasan dengan Wonogiiri) sehingga ada pemerataan pembangunan. Dalam action di lapangan, Dinas Pertanian Gunungkidul melaksanakan mekanisasi sawah dam parit, jalan usaha tani, traktorisasi, bantuan power tracer dan RMU.

Untuk meningkatkan minat generasi muda, Dinas Pertanian merancang integrasi pertanian dengan pariwisata (agrowisata). Rencana pengembangan agrowisata di Kabupaten Gunungkidul meliputi wilayah Gunung Panggung (lokasi Tambakromo); Wedi Ombo (Girisubo) kawasan buah; Sriten (Kilangrejo Nguripa) untuk manggis dan kelengkeng; Sinom (Nglipar); dan Nglanggeran untuk kebun buah durian Kencono Rukmi, sayuran.

Salah satu kelompok generasi muda yang berhasil mengelola agrowisata di Gunungkidul terdapat di Nglanggeran. Kegiatan agrowisata berhasil menarik penduduk yang telah keluar untuk kembali bekerja dalam perkebunan dan 
pariwisata. Alasan utama generasi muda memilih pengembangan agrowiisata ini adalah pendapatan yang lebih besar dibandingkan pekerjaan nonpertanian serta kesadaran pribadi setelah mendapat pelatihan dari Dinas.

Dalam pelaksanaannya, kelompok pemuda mendapat pelatihan dari Dinas Pertanian Gunungkidul dan pelatihan tanaman perkebunan. Untuk kelanjutannya, kelompok kemudian mendapat pendampingan kelembagaan dari INSTIPER serta pendampingan untuk tanaman durian dan kelengkeng dari PT. PERTAMINA

\section{b. Kabupaten Sleman}

Komoditas pertanian di Sleman sangat beragam dan terbagi atas beberapa zona. Tanaman pangan didominasi oleh padi sawah dimana petani yang mengelola berusia lanjut. Tanaman hortikultura di Sleman berkembang dengan baik terutama salak pondoh dan krisan. Salak pondoh dibudidayakan di Tempel, Turi, Pakem dan Cangkringan sedangkan krisan dibudidayakan di Desa Hargobinangun (Pakem) dan Cangkringan dan telah memiliki SOP. Pengembangan krisan sangat baik di UPT dimana ada pula fasilitas pelatihan dna pembibitan krisan. Usaha krisan mampu menarik hampir 10\% pekerja dari luar pertanian. Saat ini, petani krisan melaksanakan tanaman selingan dengan sayuran.

\footnotetext{
Pengembangan tanaman krisan mendapat dukungan penuh dari Dinas Pertanian Sleman yakni memberikan peralatan budidaya krisan. Petani krisan telah mampu
}

melaksanakan manajemen tanam dan panen sehingga harga jual krisan stabil. Subsektor hortikultura didominasi oleh generasi muda karena mampu memberikan keuntungan cukup besar. Untuk tanaman pangan, generasi muda lebih tertarik dengan usaha padi organik yang mampu memberikan keuntungan lebih besar daripada sistem budidaya padi konvensional. Untuk meningkatkan minat generasi muda maka Dinas Pertanian Sleman melaksanakaan pengenalan pertanian melalui lomba luku, lomba ani-ani untuk anak SMP, lomba tanam, desa wisata, penguatan modal, membentuk taruna tani (di Ngemplak) dan pengembangan kebun buah di Prambanan

\section{c. Kabupaten Bantul}

Generasi muda di Bantul cukup banyak yang tertarik pada usaha pertanian, terutama perbenihan dan hortikultura. Dukungan Pemkab Bantul terhadap usaha perbenihan berupa alokasi dana APBD sebesar Rp 1,3 M untuk perbenihan padi dan kedelai. Penjualan bibit padi tidak mengalami masalah sedangkan penjualan bibit kedelai bermasalah karena kebanyakan untuk industri, pakan dan campuran. Permasalahan perbenihan di Bantul adalah banyaknya benih dari luar masuk ke wilayah Bantul dan banyak yang tidak bersertifikat. Untuk tanaman pangan, 75\% merupakan petani berusia lanjut dan 25\% masih muda.

$$
\text { Tenaga kerja muda di Bantul banyak }
$$
yang berkerja di luar pertanian sehingga pemilik lahan kesulitan mencari buruh tani. Untuk pengembangan generasi muda agar 
Agus Dwi Nugroho, Lestari Rahayu Waluyati \& Jamhari. Upaya Memikat Generasi Muda Bekerja

tertarik ke pertanian, Pemkab Bantul yakni ada dana CSR dari BI untuk kursus wirausaha muda dan dana ke Gapoktan (program ketahanan pangan, sistem resi gudang) serta karang tarunan dilibatkan dalam usaha itik Turi, produksi pakan dan hormon

\section{d. Kabupaten Kulon Progo}

Generasi muda pertanian di Kulon Progo tidak tertarik ke tanaman pangan tetapi lebih memilih hortikultura yakni cabai, bawang merah, melon dan sayuran di Galur, Panjatan dan Wates karena komoditas hortikultura mampu memberikan pendapatan lebih besar. Selain itu, generasi muda (KWT) memilih untuk usaha biofarmaka lahan produk pasca panen berupa gula semut, sirup dan simplisia di Pengasih, Girimulyo dan Kokap. Usaha olahan biofarmaka mampu memberikan keuntungan finansial cukup besar bagi petani.

Program agropolitan yang diterapkan Pemkab Kulon Progo belum mampu menarik generasi muda. Dampak tidak tertariknya generasi muda ke pertanian adalah pemilik mendatangkan tenaga kerja dari luar daerah dan cenderung pada saat panen ditebas

Kondisi umum yang terjadi saat ini di DIY adalah tahap kedua dari Model Fei-Ranis yakni masih terjadi pergeseran tenaga kerja dari sektor pertanian ke nonpertanian. Secara makro, sumbangan pendapatan sektor pertanian di DIY terhadap PDRB tidak sebesar proporsi alokasi curahan kerja pada sektor pertanian Hal ini sesuai dengan gambaran dimana peranan sektor pertanian dalam penyerapan tenaga kerja dan PDRB tidak seimbang.

\section{Faktor Pendorong Pergeseran Tenaga Kerja}

Menurut Lestari (2009), adanya alih fungsi lahan pertanian ke non pertanian yang terjadi disebabkan oleh beberapa faktor dan terdapat 3 faktor penting yang menyebabkan terjadinya alih fungsi lahan pertanian khususnya sawah, yaitu:

a. Faktor Eksternal yang disebabkan adanya dinamika pertumbuhan seperti pertumbuhan perkotaan, pertumbuhan penduduk maupun pertumbuhan ekonomi.

b. Faktor Internal yang disebabkan oleh kondisi sosial-ekonomi rumah tangga pertanian pengguna lahan

c. Faktor Kebijakan atau Regulasi yang dikeluarkan oleh pemerintah pusat maupun daerah dalam mengendalikan perubahan fungsi lahan pertanian ke lahan non pertanian.

Hasil penelitian lapangan menunjukkan ada beberapa penyebab generasi muda tidak tertarik untuk bekerja di sektor pertanian, diantaranya :

\section{a. Pendapatan di Luar Sektor Pertanian lebih Besar Dibandingkan Sektor Pertanian.}

Rendahnya produktivitas tenaga kerja di sektor pertanian dibandingkan terhadap produktivitas di sektor industri dan jasa, merupakan salah satu penyebab rendahnya tingkat upah di sektor pertanian. Tenaga kerja pertanian diasumsikan melimpah sehingga 
produktivitas marjinal tenaga kerja mendekati nol dan lebih kecil dari tingkat upah.

Pembentukan pola pikir masyarakat umum juga menunjukkan bahwa pendapatan nonpertanian lebih tinggi daripada sektor pertanian. Selain itu, risiko yang ditanggung sektor pertanian juga cukup besar seperti gagal panen, bencana alam, fluktuasi harga dan lainnya sedangkan pendapatan nonpertanian bersifat lebih pasti dimana tiap bulan akan memperoleh gaji tetap. Image ini sudah melekat di masyarakat walaupun apabila dilakukan analisis pendapatan maka secara umum disimpulkan banyak pula usaha pertanian yang memberikan pendapatan lebih besar daripada sektor nonpertanian.

\section{b. Image Negatif tentang Pertanian}

Pertanian digambarkan sebagai pekerjaan yang kotor karena lumpur sawah, kerja mencangkul yang berat, harga produk/panen yang rendah, upah yang kecil, hasil panen yang dijual menghasilkan uang yang dirasa relatif kecil dan jenis pekerjaan yang dipilih sebagai alternatif terakhir. Image lain adalah jaminan untuk sukses bekerja di sektor pertanian lebih rendah dibanding daripada sektor nonpertanian, baik dari besaran upah yang diberikan maupun prospek jenjang status pekerjaan.

\section{c. Peningkatan Pendidikan Tenaga Kerja Pertanian}

Sektor pertanian tidak menuntut syarat pendidikan tertentu karena hanya melihat dari jenis pekerjaan (mencangkul, memberantas hama dan lain-lain). Sedangkan sektor nonpertanian menuntut pendidikan untuk jenjang karier. Namun kegiatan nonpertanian memiliki image memberikan upah lebih besar. Sektor nonpertanian lebih atraktif bagi tenaga kerja pedesaan (pertanian) yang memiliki keterampilan sehingga semakin tingginya tingkat pendidikan pemuda, maka pemuda akan cenderung memilih atau menginginkan bekerja di luar sektor pertanian (industri dan jasa). Penelitian Agwu, et.al (2014) mennjukkan bahwa peningkatan pendidikan di generasi muda membuat probabilitas generasi muda bekerja di sektor pertanian semakin kecil. Pendidikan yang tinggi mendorong generasi muda meninggalkan pedesaan untuk mencari pekerjaan yang mampu memberikan pendapatan lebih besar maupun keuntungan lainnya.

Struktur tenaga kerja menurut status pendidikan di DIY berdasar data mentah Sakernas (BPS) diolah oleh Pusdatin Kementerian Pertanian menunjukkan tenaga kerja pertanian di DIY didominasi oleh tenaga kerja berpendidikan maksimal SD ke bawah. Hal ini juga sejalan dengan penelitian Winarso (2014) yang meneliti tentang ketenagakerjaan pada wilayah pedesaan lahan kering di Indonesia. Pada tahun 2011, jumlah angkatan kerja di pedesaan yang tidak sekolah masih relatif tinggi berkisar 15\% dan merupakan angkatan kerja yang kurang mampu bersaing di pasar tenaga kerja yang lebih mengutamakan skill yang tinggi sehingga pada gilirannya akan masuk pada sektor yang hanya mengandalkan keterampilan dan pengalaman, seperti kegiatan berburuh di sektor pertanian dan non pertanian. 
Agus Dwi Nugroho, Lestari Rahayu Waluyati \& Jamhari. Upaya Memikat Generasi Muda Bekerja

Sektor pertanian tidak mampu memberikan perbedaan upah (wage differential) dan tidak menuntut tingkat pendidikan tertentu. Sementara itu sektor nonpertanian mampu memberikan perbedaan upah yang nyata dan tingkat pendidikan secara jelas menjadi syarat untuk akses ke sektor nonpertanian. Pertanian yang didominasi tenaga kerja berpendidikan rendah menyebabkan sektor lambat untuk berkembang karena pelaku usaha pertanian cenderung tidak mampu untuk melakukan maupun menerima inovasi karena keterbatasan pola pikir para pelakunya.

Tabel 3 Proyeksi Jumlah Tenaga Kerja Sektor Pertanian Berdasarkan Tingkat Pendidikan di DIY Tahun 2014

\begin{tabular}{lc}
\hline Tingkat Pendidikan & Jumlah Tenaga Kerja (jiwa) \\
\hline Tidak/Belum & 82.894 \\
Pernah Sekolah & \\
Tidak Tamat SD & 122.029 \\
SD & 153.672 \\
SLTP & 79.653 \\
SMA & 39.560 \\
SMK & 36.226 \\
Diploma I/II/III & 5.349 \\
Universitas/D IV & 3.371 \\
\hline Jumlah & 522.754 \\
\hline
\end{tabular}

Sumber: data mentah Sakernas (BPS) diolah oleh Pusdatin Kementerian Pertanian

d. Kepemilikan Lahan Pertanian yang Sempit

Kepemilikan lahan pertanian di DIY terus mengalami penurunan karena laju konversi lahan. Alih fungsi lahan di DIY didorong motif ekonomi sehingga petani berlomba menjual lahan usahataninya dan membuat petani tidak mempunyai lahan ataupun sudah terlalu sempit untuk mampu menghasilkan produksi yang mampu mencukupi kebutuhan hidup.

Penurunan jumlah cukup besar juga terjadi pada rumah tangga dengan kepemilikan lahan yang rendah. Semakin terbatasnya lahan pertanian diikuti dengan peningkatan angkatan kerja di pedesaan karena pertambahan jumlah penduduk. Kepemilikan lahan pertanian yang luasannya kecil dan terfragmentasi mengakibatkan pendapatan petani yang semakin berkurang dan berimbas pada keputusan petani untuk menjual atau merubah lahan pertaniannya ke lahan usaha non pertanian. Walaupun nilai persentasenya tidak yang paling besar, akan tetapi bila dilihat dari absolut jumlah rumah tangganya adalah yang paling besar. Sedangkan di sisi lain, kesempatan kerja di luar sektor pertanian seperti: jasa, perdagangan dan industri menjadi semakin terbuka sehingga mendorong angkatan kerja muda lebih memilih pekerjaan sektor nonpertanian menjadi sumber pendapatan bagi rumah tangga masyarakat pedesaan.

Tabel 4 Jumlah Rumah Tangga Usaha Pertanian Menurut Luas Kepemilikan Lahan Rumah Tangga Tahun 2013

\begin{tabular}{lllll}
\hline \multirow{2}{*}{$\begin{array}{l}\text { Golongan Luas Lahan } \\
\left(\mathrm{m}^{2}\right)\end{array}$} & \multicolumn{2}{l}{ Rumah Tangga Usaha Pertanian } & \multicolumn{2}{l}{ Pertumbuhan } \\
\cline { 2 - 5 } & 2003 & 2013 & Absolut & $\%$ \\
\hline$<1000$ & 198,202 & 157,002 & $-41,200$ & -20.79 \\
$1000-1999$ & 119,323 & 118,659 & -664 & -0.56 \\
$2000-4999$ & 164,077 & 149,273 & $-14,804$ & -9.02 \\
$5000-9999$ & 69,252 & 54,092 & $-15,160$ & -21.89 \\
$10000-19999$ & 20,265 & 14,289 & $-5,976$ & -29.49 \\
$20000-29999$ & 2,807 & 1,718 & $-1,089$ & -38.8 \\
$\geq 30000$ & 994 & 748 & -246 & -24.75 \\
\hline Jumlah & 574,920 & 495,781 & $-79,139$ & -13.77 \\
\hline
\end{tabular}

Sumber: Sensus Pertanian 2013 

Agus Dwi Nugroho, Lestari Rahayu Waluyati \& Jamhari. Upaya Memikat Generasi Muda Bekerja

Selain penurunan luas lahan, status kepemilikan lahan menjadi pendorong generasi muda lebih memilih sektor nonpertanian. Sebagian generasi muda tidak memiliki lahan sehingga tidak memiliki kesempatan bekerja di sektor pertanian.

\section{e. Kemudahan Aksesbilitas Pedesaan}

Perkembangan perekonomian desa di DIY yang semakin terbuka mendorong semakin baiknya aksesbilitas pedesaan terhadap pusat-pusat ekonom di kota kabupaten serta lancarnya arus informasi dan komunikasi. Hal ini membuat akses generasi muda ke pekerjaan sektor nonpertanian juga semakin mudah. Kesempatan kerja di luar sektor pertanian yang bisa memberi pendapatan keluarga yang lebih besar, kecuali pada daerah dengan aksesbilitas yang rendah dan kurang terjangkau oleh lembaga ekonomi dimana kesempatan kerja hanya terbatas pada sektor pertanian sebagai sektor andalan.

\section{Faktor Penarik Generasi Muda Pertanian}

\section{a. Finansial}

Hasil observasi lapangan menunjukkan bahwa ketertarikan generasi muda beraktivitas di pertanian adalah karena faktor finansial dimana generasi muda telah mampu mengelola usaha pertanian dengan baik sehingga mampu menghasilkan pendapatan di atas usaha nonpertanian. Namun usaha pertanian yang menarik generasi muda telah memilki spesifikasi yakni usaha perbenihan, hortikultura, olahan dan pemasaran hasil pertanian serta agrowisata. Keadaan ini sesuai dengan penelitian Hamyana (2017) dimana penarik generasi muda bekerja di sektor pertanian karena motif rasional structural base atau bekerja di bidang pertanian dipahami sebagai sebuah pilihan yang didasarkan pada seberapa besar pilihan tersebut memberikan keuntungan baik secara ekonomi, sosial, maupun lingkungan.

\section{b. Warisan Orang Tua}

Faktor budaya untuk meneruskan usaha orang tua merupakan faktor pendorong berikutnya. Generasi muda cenderung untuk melanjutkan usaha orang tua. Keadaan ini terjadi hampir di semua responden dimana generasi muda memperoleh warisan lahan dari orang tua. Namun komoditas yang dikelola oleh generasi muda berbeda dengan komoditas yang dikelola orang tua. Generasi muda bersifat lebih adaptif dalam mengembangkan komoditas dengan melihat potensi pasar. Keadaan ini sesuai dengan penelitian Hamyana (2017) dimana salah penarik generasi muda bekerja di sektor pertanian adalah motif moral-cultural base atau bekerja kerja di bidang pertanian dimaknai bukan sekedar persoalan rasional untung atau rugi, melainkan sebuah panggilan jiwa, sebuah tanggung jawab moral yang harus diemban generasi penerus pembangunan dalam melawan dominasi dan hegemoni paham modernisme, hedonisme, dan westernisasi yang menurut mereka ide dan gagasannya tidak seirama dengan nilai-nilai luhur yang dibangun oleh nenek moyang.

\section{c. Insentif dari Pemerintah}

Generasi muda pertanian tertarik dengan pertanian dalam konsep modern 
dimana aktivitas pertanian dijalankan dengan berbagai paket teknologi. Hal ini sesuai dengan penelitia Silaban dan Sugiharto (2016) dimana pembangunan pertanian saat ini berorientasi pada teknologi dan merupakan salah satu syarat mutlak pertumbuhan pertanian.

Hasil observasi lapngan menunjukkan bahwa semakin aktif Pemkab dalam memberikan insentif dan pelatihan di bidang pertanian maka semakin banyak generasi muda yang tertarik untuk beraktivitas di sektor pertanian. Selain itu, dukungan alat mesin modern membuat generasi muda tertarik dengan pertanian karena kemudahan dalam pengelolaan komoditas. Temuan di lapangan ini juga selaras dengan hasil penelitian Supriyati (2010) dimana upaya peningkatan minat generasi muda kepada sektor pertanian dapat dilakukan melalui pembangunan karakter generasi muda yang tangguh dan cinta pertanian melalui program insentif.

Beberapa insentif yang dilakukan pemerintah beberapa negara untuk mendorong generasi muda melaksanakan kegiatan pertanian antara lain (Susilowati, 2015)

Tabel 5 Skema Insentif Untuk Generasi Muda Pertanian

\begin{tabular}{|l|l|l|l|}
\hline No & Negara & Jenis Insentif & Target \\
\hline 1 & Eropa & Skema dana hibah dan subsidi bagi petani baru & $\begin{array}{l}\text { Petani di bawah usia 35 } \\
\text { tahun }\end{array}$ \\
\hline 2 & Australia & $\begin{array}{l}\text { Fasilitas pinjaman bunga rendah untuk } \\
\text { pembelian alat mesin pertanian, tanah dan } \\
\text { lainnya }\end{array}$ & $\begin{array}{l}\text { Petani di bawah usia 40 } \\
\text { tahun }\end{array}$ \\
\hline 3 & Prancis & $\begin{array}{l}\text { Pinjaman bersubsidi untuk membeli tanah dan } \\
\text { pengurangan pajak }\end{array}$ & $\begin{array}{l}\text { Petani di bawah usia 40 } \\
\text { tahun }\end{array}$ \\
\hline 4 & Inggris & $\begin{array}{l}\text { Dana bantuan dan penyuluhan/pembimbinan } \\
\text { dari pihak profesional pertanian }\end{array}$ & $\begin{array}{l}\text { Petani di bawah usia 40 } \\
\text { tahun }\end{array}$ \\
\hline 5 & Kanada & $\begin{array}{l}\text { Pinjaman bergaransi, Inovasi produk dan } \\
\text { pengurangan suku bunga pinjaman untuk } \\
\text { pendidikan dan pelatihan pertanian }\end{array}$ & $\begin{array}{l}\text { Petani di bawah usia 40 } \\
\text { tahun }\end{array}$ \\
\hline 6 & Amerika Serikat & $\begin{array}{l}\text { Bunga rendah pinjaman selama 5 tahun (1,5\%) } \\
\text { Petani pemula }\end{array}$ \\
\hline
\end{tabular}

\section{Dampak Pergeseran Tenaga Kerja Pertanian}

\section{a. Penurunan Efektivitas dan Efisiensi Sektor Pertanian}

Hingga saat ini kondisi masyarakat petani dihadapkan pada kecilnya skala penguasaan dan pengusahaan lahan petani yang mengakibatkan terbatasnya pendapatan petani. Keadaan ini selaras dengan penelitian Thamrin, dkk (2012) yang menyebutkan bahwa usia petani yang muda akan berdampak pada peningkatan pendapatan karena petani muda bersifat lebih adaptif terhadap teknologi baru. Selain itu, penggunaan input pertanian juga tidak optimal dan mahal sehingga menyebabkan produktivitas pengusahaan dan kualitas tanaman pertanaman, terutama palawija, menjadi rendah. Rendahnya minat generasi muda cerdas terdidik dari dunia pertanian akan menyulitkan dunia pertanian karena tidak akan ada lagi generasi petani yang memiliki pengetahuan yang cukup untuk mengatasi berbagai persoalan pertanian yang semakin kompleks. 


\section{b. Kelangkaan Tenaga Kerja Pertanian dan Kenaikan Upah}

Mobilitas tenaga kerja dicirikan oleh pergerakan tenaga kerja dari sektor dengan produktivitas rendah (pertanian) ke sektor dengan tingkat produktivitas tinggi (manufaktur) dengan konsekuensi kelangkaan tenaga kerja di pertanian. Penelitian Ando dan Horiguchi (2013) menunjukkan bahwa pertanian di Jepang juga mengalami kelangkaan tenaga kerja muda sehingga menyebabkan upah tenaga kerja pertanian cukup mahal. Hal ini sangat dirasakan oleh petani yang memiliki lahan cukup luas sehingga solusi yang diambil adalah menggunakan tenaga kerja asing yang telah mendapatkan pelatihan teknis dari pemerintah (Technical Intern Training Program).

HasIl observasi lapangan juga menunjukkan bahwa pemilik lahan kesulitan untuk mencari buruh penggarap sehingga pemilik lahan memberikan lebih berani untuk memberikan upah yang tinggi bagi buruh tani. Hal ini sesuai dengan supply dan demand tenaga kerja dimana pada daerah langka tenaga kerja, tingkat upah akan lebih tinggi ketimbang daerah yang surplus tenaga kerja. Elastisitas tenaga kerja terhadap produktivitas relatif tinggi dan tingkat upah berdampak negatif inelastis terhadap penawaran dan keuntungan usaha tani padi. Hasil penelitian Khakim, dkk (2013) menunjukkan bahwa penambahan tenaga kerja dapat menyebabkan kenaikan produksi petani sehingga apabila terjadi kelangkaan atau kekurangan tenaga kerja akan menyebabkan penurunan produksi pertanian.

\section{Kebijakan Menarik Generasi Muda ke Pertanian}

Berdasarkan peraturan yang ada, maka ada beberapa kebijakan yang perlu dilakukan untuk meningkatkan minat generasi muda dalam pertanian. Pengembangan pertanian di DIY, terutama melalui generasi muda, harus tetap mengutamakan budaya lokal sehingga selain sebagai kegiatan ekonomi, pertanian tetap mampu menjaga kekhasan lokal. Beberapa kekhasan yang dimiliki pertanian di DIY yang membedakan dengan wilayah lain antara lain pertanian ramah lingkungan atau pertanian organik, pertanian terpadu, Jogja Benih, pewilayahan komoditi atau zonasi wilayah, agrowisata, kelembagaan lokal, varietas lokal unggul, teknologi lokal unggul dan pendekatan koperasi atau korporasi.

Kebijakan yang dapat disusun dalam Peraturan Daerah atau Peraturan Gubernur antara lain :

a. Mengoptimalkan kelembagaan petani dengan meningkatkan peran pemuda dalam sektor pertanian melalui pemantaban kelompok tani dengan pemberdayaan kelompok taruna bumi, taruna tani dan wirausaha petani muda

Kebijakan Menteri Pertanian dalam pengembangan generasi muda pertanian salah satunya adalah pembentukan organisasi kepemudaan di bidang pertanian yakni taruna bumi dan taruna tani. Peraturan Menteri Pertanian No 7 
Agus Dwi Nugroho, Lestari Rahayu Waluyati \& Jamhari. Upaya Memikat Generasi Muda Bekerja

Tahun/Permentan/OT.140/1/2013 mengatur tentang pengenalan pertanian untuk generasi muda pertanian. Untuk itu, Pemerintah DIY perlu mendorong tiap kelompok tani untuk memiliki sub bagian sebagai wadah bagi generasi muda baik itu taruna bumi atau taruna tani atau wirausaha petani muda. Apabila pembentukan lembaga pemuda tani sulit diwujudkan, maka langkah yang dapat dilaksanakan yakni mendorong dalam struktur organisasi kelompok tani untuk membentuk kelompok pemuda. Kelompok pemuda ini selain menjadi bagian kelompok yang adaptif terhadap inovasi teknologi juga menjadi wadah bagi regenerasi di kelompok tani.

\section{b. Pengenalan pertanian melalui pendidikan usia dini, pengembangan kurikulum dan ekstrakurikuler berbasis pertanian di sekolah umum serta peningkatan kualitas pelaku pertanian melalui pendidikan pelatihan dan pendampingan}

Pengenalan pertanian untuk anak sekolah perlu dilaksanakan dalam rangka membentuk karakter anak cinta pertanian. Pendidikan di usia dini tidak hanya pendidikan akan pengetahuan umum melainkan juga pendidikan moral dan etika serta pengenalan lingkungan sudah ditanamankan sejak pendidikan dasar. Sebagai contoh di kota Gifushi (Jepang), mempunyai semacam pusat lingkungan air tawar (Aqua Toto). Kompleks ini dibangun di Sungai Kiso (Kiso-gawa). Di kompleks ini selain semacam aquarium ekosistem air tawar juga terdapat semacam pusat studi lingkungan (River Environmental
Centre). Di pusat studi ini sering menjadi rujukan untuk pengenalan mengenai ekosistem dan pengelolaannya. Anak-anak Sekolah Dasar selain dijelaskan dalam kelas/ruang juga diajak untuk menangkap ikan atau udang air tawar di sungai dangkal. Hal ini sangat luar biasa menanmkan kepada anak usia dini mengenai sangat pentingnya lingkungan bagi kehidupan.

Banyak kegiatan yang dapat dilakukan untuk pendidikan usia dini dalam rangka pengenalan pertanian baik secara formal maupun informal. Secara formal, pengenalan pertanian dilakukan dengan memasukkan pengenalan pertanian untuk kegiatan muatan lokal atau ekstrakurikuler serta dapat berupa kebun atau media tanam sekolah. Untuk mengevaluasi program ini maka dapat dilakukan lomba pertanian usia dini tingkat daerah. Sedangkan secara informal cukup banyak yang dapat dilakukan. Salah satunya Agricultural Training Camp (ATC) adalah salah satu bentuk diklat pertanian yang diperuntukan bagi anak usia sekolah untuk memberi pengetahuan dan keterampilan di bidang pertanian sehingga tumbuh dan berkembang apresiasi (minat dan kecintaan) terhadap pertanian. Kegiatan lain adalah dengan membuat rumah pengenalan pertanian di fasilitas umum yang banyak dikunjungi anak-anak seperti taman pintar dan taman pelangi atau tempat lain.

Pengenalan pertanian juga ditujukan bagi orang tua sebagai pembuka wawasan agar orang tua memberikan izin bagi anak untuk beraktivitas di pertanian. Orang tua 
diperkenalkan dengan sistem pertanian yang prospektif secara finansial.

Pendidikan merupakan faktor yang sangat penting dalam membentuk kualitas dan kapasitas sumber daya manusia di sektor pertanian. Salah satu cara meningkatkan minat generasi muda adalah melalui pendidikan pertanian sehingga dihasilkan generasi muda yang memiliki spesialisasi di bidang pertanian. Pendidikan diterapkan baik secara formal melalui sekolah pertanian maupun nonformal dengan konsentrasi untuk karang taruna. Pendidikan pertanian memberi pencerahan kepada tenaga kerja sehingga menumbuhkan keberdayaan melalui peningkatan kapasitas dan kompetensi tenaga kerja pertanian. Tenaga kerja muda ini nantinya akan berhubungan dengan alat-alat dan teknologi informasi canggih di bidang pertanian sehingga mampu meningkatkan efektivitas petanian.

Pendidikan dan pelatihan antara lain berupa:

1) Pengembangan program pelatihan dan pemagangan;

2) Pemberian beasiswa bagi petani untuk mendapatkan pendidikan di bidang pertanian; atau

3) Pengembangan pelatihan kewirausahaan di bidang agribisnis.

Penyuluhan dan pendampingan dilakukan antara lain agar petani dapat melakukan:

1) Tata cara budi daya, pascapanen pengolahan, dan pemasaran yang baik;

2) Analisis kelayakan usaha; dan
3) Kemitraan dengan Pelaku Usaha

Jenis pendidikan lainnya yang dibutuhkan adalah kewirausahaan. Generasi muda yang memiliki jiwa wiraswasta yang tangguh untuk mengembangkan berbagai sektor terutama di bidang pertanian, perkebunan maupun peternakan. Generasi muda yang menguasasi kewirausahaan akan menciptakan banyak peluang kerja sehingga menyerap banyak tenaga kerja.

\section{c. Mengembangkan pertanian terpadu berbasis Agroforestry, Agroindustri, Agropolitan dan Agrowisata serta Minapolitan}

Salah satu misi Kementerian Pertanian tahun 2010-2014 adalah mewujudkan usaha pertanian yang terintegrasi secara vertikal dan horizontal guna menumbuhkan usaha ekonomi produktif dan menciptakan lapangan kerja di pedesaan. Pertanian terpadu merupakan pola integrasi beberapa unit usaha pertanian yang dikelola secara terpadu, berorientasi ekologis dan ekonomis dengan peningkatan efisiensi. Pertanian terpadu mengintegrasikan tanaman pangan, hortikultura, perkebunan dan peternakan melalui sinergitas antar unit dengan mengedepankan kelestarian lingkungan dan peningkatan secara ekonomis karena penambahan efisiensi dan nilai produktivitas.

Sistem pertanian terpadu pertaniankehutanan-perkebunan (agroforestry) digunakan untuk mengurangi penebangan hutan untuk lahan pertanian dan solusi untuk keterbatasan lahan pertanian. Salah satu 
Agus Dwi Nugroho, Lestari Rahayu Waluyati \& Jamhari. Upaya Memikat Generasi Muda Bekerja

bentuk sistem pertanian terpadu pertaniankehutanan adalah agroforestry yaitu penanaman tanaman tahunan dengan tanaman semusim. Penanaman tanaman tahunan diberi sela dengan tanaman semusim. Manfaat pertanian dalam kehutanan/perkebunann adalah dapat dihasilkan produk yang lebih dan meningkatkan nilai ekonomis. Tanaman tahunan merupakan pendapatan petani untuk jangka panjang sedangkan tanaman semusim merupakan sumber pendapatan petani untuk jangka pendek. Integrasi tanaman pangan dengan kehutanan/perkebunan dapat diterapkan di wilayah Gunungkidul dan Kulon Progo.

Belum berkembangnya agoindustri di perdesaan, sehingga usaha tani masih dominan di aspek produksi on-farm dengan tingkat pendapatan yang relatif kecil dan belum berkembangnya usaha jasa pelayanan permodalan, dan teknologi. Kondisi ini kurang menarik minat generasi muda di perdesaan untuk bekerja dan berusaha di bidang pertanian. Untuk menarik generasi muda maka DIY perlu merancang pengembangan pertanian di perdesaan berbasis agroindustri. Agroindustri merupakan konsep yang berkonsentrasi pada pengolahan komoditas pertanian dan limbah pertanian. Perkembangan negara maju pada awalnya dibangun atas dasar industri pertanian di perdesaan sehingga mampu meningkatkan taraf ekonomi masyarakat dan menciptakan lapangan kerja.

Basis pengembangan agroindustri di DIY adalah usaha olahan komoditas hortikultura karena variasi produksi komoditas hortikultura cukup banyak dengan SDM yang cukup berkualitas. Contoh usaha agroindustri di DIY yang cukup sukses semisal olahan salak di Sleman dan olahan biofarmaka. Untuk pengembangan agroindustri maka DIY perlu menyusun roadmap lokasi agroindustri serta fasilitas alat mesin pengolahan.

Pengembangan kawasan agropolitan merupakan penguatan sentra-sentra produk pertanian yang berbasiskan pada kekuatan internal sehingga perdesaan menjadi kawasan yang memiliki pertumbuhan ekonomi dan daya kompetensi, baik secara interregional maupun intraregional.daya. Penerapan agropolitan sebenarnya pernah diterapkan di wilayah Kalibawang (Kulon Progo) dengan komoditas unggulan durian serta komoditas lain. Namun kenyataannya belum mampu menyerap generasi muda untuk berpartisipasi pada sektor pertanian bahkan pada musim panen padi di wilayah Kalibawang sebagian besar tenaga kerja berasal dari wilayah luar.

Untuk meningkatkan optimalisasi pengembangan agropolitan maka kegiatan yang dikembangkan harus bersifat bottom up dan nerupakan kegiatan kegiatan yang langsung melibatkan masyarakat. Untuk meningkatkan peran generasi muda maka agropolitan dibangun dengan menggerakkan kegiatan pengolahan dan atau pemasaran di sentra produksi unggulan karena kedua kegiatan ini mampu menarik banyak tenaga kerja muda.

Integrasi sektor pariwisata dengan pertanian (agrowisata) di DIY sangat 
berpotensi untuk berkembang dengan cepat. Agrowisata merupakan salah satu bentuk kegiatan wisata yang dilakukan di kawasan pertanian yang menyajikan pemandangan alam kawasan pertanian dan aktivitas di dalamnya seperti persiapan lahan, penanaman, pemeliharaan, pemanenan, pengolahan hasil panen sampai dipasarkan bahkan wisatawan dapat membeli produk pertanian tersebut sebagai oleh-oleh. Pada tiap kabupaten di DIY memiliki potensi agrowisata berupa aset untuk menarik kunjungan wisatawan berupa keindahan alam. Beberapa contoh agrowisata di DIY telah berhasil menarik generasi muda pertanian. Untuk meningkatkan peran agrowisata, pemerintah daerah dapat bekerja sama dengan travel agent dimana daerah agrowisata menjadi salah satu rute wisata,

\section{d. Penguatan Cooperative Farming sehingga Ada Jaminan Luasan Lahan Pertanian yang Mempunyai Skala Ekonomi Tertentu Berlandaskan Budaya DIY}

Permasalahan terkait lahan adalah kepemilikan lahan yang sempit sehingga perlu ada suatu perencanaan dengan membentuk integrasi lahan (cooperative farming) sehingga dapat terbentuk suatu hamparan seperti yang telah dilaksanakan di Kabupaten Bantul. Integrasi lahan digunakan untuk mengatasi tidak efisiennya pertanian karena secanggih apapun teknologi pendukung pertanian yang digunakan tidak akan efektif tanpa didukung luas lahan yang cukup. Cooperative farming pertanian merupakan penataan kembali penggunaan dan pemanfaatan lahan sesuai dengan potensi dan rencana tata ruang wilayah untuk kepentingan lahan pertanian. Pemerintah DIY dapat mengkoordinasi kelompok tani yang ada untuk bersama-sama membentuk hamparan. Tiap anggota kelompok akan memperoleh bagi hasil sesuai dengan luasan lahan yang dimiliki atau dapat dikatakan sistem ini seperti pembagian dividen berdasarkan saham yang dimiliki. Hal ini juga dapat diterapkan pada sistem warisan dimana DIY perlu secara perlahan mengubah budaya dengan sistem saham. Anak yang berminat melanjutkan usaha pertanian maka dapat mengelola usaha sedangkan anak yang tidak berminat melanjutkan usaha pertanian dapat berkerja di sektor lain namun tetap mendapat saham atas lahan yang dikelola. Apabila kebijakan ini berhasil maka skala ekonomi pertanian akan menarik dan dapat menarik generasi muda untuk beraktivitas di sektor pertanian.

\section{e. Asuransi Pertanian}

Asuransi pertanian atau ganti rugi gagal panen akibat kejadian luar biasa dilakukan untuk melindungi petani dari kerugian gagal panen akibat bencana alam; serangan organisme pengganggu tumbuhan; wabah penyakit hewan menular; dampak perubahan iklim; dan/atau jenis risiko-risiko lain diatur dengan Peraturan Gubernur. Sedangkan pemberian fasilitas pembiayaan dan permodalan dilakukan dengan pinjaman modal untuk memiliki dan/atau memperluas kepemilikan lahan Pertanian; pemberian 
Agus Dwi Nugroho, Lestari Rahayu Waluyati \& Jamhari. Upaya Memikat Generasi Muda Bekerja

bantuan penguatan modal bagi petani; pemberian subsidi bunga kredit program dan/atau imbal jasa penjaminan; dan/atau pemanfaatan dana tanggung jawab sosial serta dana program kemitraan dan bina lingkungan dari badan usaha

\section{f. Jaminan Pemasaran}

Jaminan pemasaran dapat dilakukan melaluipembelian secara langsung; penampungan hasil usaha tani; dan/atau pemberian fasilitas akses pasar serta pengembangan sistem dan sarana pemasaran hasil pertanian dengan:

1) Mewujudkan pasar hasil pertanian yang memenuhi standar keamanan pangan, sanitasi, serta memperhatikan ketertiban umum;

2) Mewujudkan terminal agribisnis dan subterminal agribisnis untuk pemasaran hasil Pertanian;

3) Mewujudkan fasilitas pendukung pasar hasil Pertanian;

4) Memfasilitasi pengembangan pasar hasil Pertanian yang dimiliki dan/atau dikelola oleh Kelompok Tani, Gabungan Kelompok Tani, koperasi, dan/atau kelembagaan ekonomi Petani lainnya di daerah produksi Komoditas Pertanian;

5) Membatasi pasar modern yang bukan dimiliki dan/atau tidak bekerja sama dengan Kelompok Tani, Gabungan Kelompok Tani, koperasi, dan/atau kelembagaan ekonomi Petani lainnya di daerah produksi Komoditas Pertanian;
6) Mengembangkan pola kemitraan Usaha Tani yang saling memerlukan, mempercayai, memperkuat, dan menguntungkan;

7) Mengembangkan sistem pemasaran dan promosi hasil Pertanian;

8) Mengembangkan pasar lelang;

9) Menyediakan informasi pasar; dan

10) Mengembangkan lindung nilai.

\section{SIMPULAN}

Gambaran umum kondisi tenaga kerja pertanian di DIY adalah jumlah rumah tangga dan perusahaan pertanian di DIY mengalami penurunan. Partisipasi generasi muda do sektor pertanian semakin menurun serta struktur usia tenaga kerja pertanian di DIY didominasi penduduk berusia 60 tahun ke atas dengan jumlah generasi muda yang beraktivitas di pertanian masih sedikit bahkan diproyeksikan akan terus menurun sedangkan petani berusia lanjut terus akan meningkat. Faktor pendorong pergeseran generasi muda dari sektor pertanian ke sektor nonpertanian antara lain pendapatan di luar sektor pertanian lebih besar dibandingkan sektor pertanian, image negatif pertanian, peningkatan pendidikan, kepemilikan lahan pertanian yang sempit dan kemudahan aksesbilitas pedesaan. Sedangkan faktor penarik generasi muda ke sektor pertanian antara lain finansial, warisan orang tua dan insentif pemerintah. Adapun dampak pergeseran generasi muda dari sektor pertanian ke sektor nonpertanian antara lain penurunan efektivitas dan efisiensi sektor 
pertanian serta kelangkaan tenaga kerja pertanian dan kenaikan upah. Untuk mengatasinya maka diperlukan kebijakan antara lain mengoptimalkan kelembagaan petani dengan meningkatkan peran pemuda dalam sektor pertanian; pengenalan pertanian melalui pendidikan usia dini, pengembangan kurikulum dan ekstrakurikuler berbasis pertanian di sekolah umum serta peningkatan kualitas pelaku pertanian melalui pendidikan pelatihan dan pendampingan; mengembangkan pertanian terpadu; penguatan cooperative farming; asuransi pertanian dan jaminan pemasaran.

\section{DAFTAR PUSTAKA}

Agwu, N.M., Nwankwo, E.E and Anyanwu, C.I. (2014). Determinants of Agricultural Labour Participation Among Youths in Abia State, Nigeria. International Journal of Food and Agricultural Economics 2 (1): 157-164.

Ando, I and K. Horiguchi. (2013). Japanese Agricultural Competitiveness and Migration. Migration Letters 10 (2): 144 - 158.

Anonim, (2013). Pendidikan Usia Dini di Jepang. Diunduh www.ariyanto.staff.uns.ac.id/2013/09/30/p endidikan-usia-dini-di-jepang tanggal 22 Desember 2017.

Cassidy, A and B. Mcgrath. (2015). Farm, Place and Identity Construction Among Irish Farm Youth Who Migrate. Journal of Rural Studies 37 (1) : $20-28$.
Hamyana, (2017). Motif Kerja Generasi Muda di Bidang Pertanian: Studi Fenomenologi tentang Motif Kerja di Bidang Pertanian pada Kelompok Pemuda Tani di Kota Batu. Mediapsi 3 (1) : 34-42.

Khakim, L., D. Hastuti dan A. Widiyani. (2013). Pengaruh Luas Lahan, Tenaga Kerja, Pemggunaan Benih dan Penggunaan Pupuk terhadap Produksi Padi di Jawa Tengah. Mediagro 9 (1): 71-79.

Lestari, T. (2009). Dampak Konversi Lahan Pertanian bagi Taraf Hidup Petani. Bogor: IPB Press.

Prawesti, N., R. Witjaksono dan A.B. Raya. (2010). Motivasi Anak Petani menjadi Petani. Agro Ekonomi 17 (1): 11-18.

Silaban, L. R dan Sugiharto, (2016). Usaha-usaha yang Dilakukan Pemerintah dalam Pembangunan Sektor Pertanian. Jurnal Ilmu Pemerintahan dan Sosial Politik UMA 4 (2): 196-210

Supriyati, (2010). Dinamika Ekonomi Ketengakerjaan Pertanian: Permasalahan dan Kebijakan Strategis Pembangunan. Analisis Kebijakan Pertanian 8 (1): 49-65.

Susilowati, S. H. (2015). Attracting the Young Generation to Engage in Agriculture. Proceedings The FFTC-RDA International Seminar on Enhanced Entry of Young Generation into Farming. Jeonju, Oct 20-24, page: $1-17$.

Thamrin, M., S. Herman dan F. Hanafi. (2012). Pengaruh Faktor Sosial Ekonomi terhadap Pendapatan Petani Pinang. Agrium 17 (2): 85-94.

Winarso, B. (2014). Dinamika Ketenagakerjaan pada Wilayah Pedesaan Lahan Kering di Indonesia. Jurnal Penelitian Pertanian Terapan 14 (1): 1-14. 